\title{
Neurofibromin and NF1 Gene Analysis in Composite Pheochromocytoma and Tumors Associated with von Recklinghausen's Disease
}

\author{
Noriko Kimura, M.D., Toshiya Watanabe, M.D., Masayuki Fukase, M.D., Atsushi Wakita, Ph.D., \\ Takao Noshiro, M.D., Itaru Kimura, M.D. \\ Department of Pathology and Laboratory Medicine (NK), Tohoku Rosai Hospital, Sendai; Department of \\ Pathology (NK) and 2nd Department of Internal Medicine (TW, TN), Tohoku University Graduate School \\ of Medical Science, Sendai; Department of Pathology (MF), Shounai City Hospital, Tsuruoka, Yamagata; \\ Research Department B, Gene Analysis Group, Mitsubishi Kagaku Bio-Clinical Laboratories, Inc., Tokyo \\ $(A W)$; and Department of Neurology (IK), National Yamagata Hospital, Yamagata, Japan
}

Composite tumor of pheochromocytoma and neuroblastoma, or ganglioneuroma, or ganglioneuroblastoma (composite pheochromocytoma), also known as mixed neuroendocrine and neural tumor, are sometimes combined with neurofibromatosis type 1 (NF1). To better understand the relationship between NF1 and composite pheochromocytoma, an immunohistochemical study using anti-neurofibromin that is an NF1 gene product and DNA sequence of NF1 Exon 31 were carried out in five cases of composite pheochromocytoma and in various tumors from five patients with NF1. Neurofibromin was not expressed in Schwann cells and sustentacular cells of composite pheochromocytomas and was very weakly or negatively expressed in neurofibroma of NF1 patients. However, it was strongly expressed in ganglionic cells and pheochromocytoma cells of the composite pheochromocytomas and also in mucosal ganglioneuromas, a gangliocytic paraganglioma, and in pheochromocytomas from the patients with NF1. Although there was no mutation in NF1 Exon 31, it could not be ruled out that there were mutations in other sites of the NF1 gene. Neurofibromin insufficiency may induce abnormal proliferation of Schwann cells in composite pheochromocytomas as well as in neurofibromatosis.

KEY WORDS: Composite pheochromocytoma, Immunohistochemistry, Knockout mouse, Neurofi-

Copyright (C) 2002 by The United States and Canadian Academy of Pathology, Inc.

VOL. 15, NO. 3, P. 183, 2002 Printed in the U.S.A

Date of acceptance: November 19, 2001.

Address reprint requests to: Noriko Kimura, M.D., Department of Pathology and Laboratory Medicine, Tohoku Rosai Hospital, 21-3-4 Dainohara Aoba-ku Sendai, 981-8563, Japan; e-mail: nkimura-path@ tohokuh.rofuku.go.jp; fax: 81-22-275-7541. bromin, NF1 gene, S100 protein, von Recklinghausen's disease.

Mod Pathol 2002;15(3):183-188

A composite tumor of pheochromocytoma and ganglioneuroblastoma (GNB) or ganglioneuroma (GN) or neuroblastoma is a rare tumor of the adrenal medulla or retroperitoneum. This tumor is classified as composite pheochromocytoma in the World Health Organization tumor classification (1). It has been previously reported that this peculiar tumor is sometimes combined with von Recklinghausen's disease (NF1; 2-5). The NF1 is transmitted by autosomal-dominant inheritance, apparently via a single loss-of-function allele of the gene designated NF1 (6). The NF1 gene product, neurofibromin, contains a region homologous to that corresponding to mammalian RasGTPase activating proteins that function as negative regulators of Ras by accelerating the conversion of Ras-GTP to Ras-GDP. The NF1 gene appears to function as a tumor suppressor gene (7). Tumors occurring in patients with NF1 often show the loss of remaining wild-type allele of the functionally defective neurofibromin $(6,8)$. The predicted amino acid sequences of the human and mouse neurofibromin proteins are $98 \%$ identical, and there also is significant similarity in the 3 ' noncoding region of the $\mathrm{mR}$ NAs (9). To study NF1 gene function, Jacks et al. (10) have constructed a mouse strain carrying a knockout mutation of Nfl, the murine counterpart of human NF1. Homozygous inheritance of the mutation is lethal during development. However, heterozygous animals with a mutant allele neo gene inserted into Exon 31 of $\mathrm{Nf1}\left(\mathrm{Nfl}^{\mathrm{n} 31}\right)$ survive into adult life and are highly predisposed to the formation of various tumor types, notably pheochromocytoma, and myeloid leukemia, both of which occur with increased frequency in human NF1 patients. The pheochromocytomas in- 
duced in the $\mathrm{Nf}^{\mathrm{n} 31}$ mouse exhibited variable morphology, and some of them also resembled human pheochromocytoma with small areas of ganglioneuromatous differentiation (11). Those cells in primary cultures typically show extensive spontaneous neuronal differentiation (12). Although those investigators did not use the term composite pheochromocytoma for the induced tumors by $\mathrm{Nfl}^{\mathrm{n} 31}$, their reports encouraged us to determine whether there is an NF1 exon 31 gene mutation in composite pheochromocytoma in humans. We also immunohistochemically investigated neurofibromin, which is a NF1-GAPrelated protein (NF1GRP) in composite pheochromocytoma, and compared neurofibromin expression in various tumors from five patients with NF1.

\section{MATERIALS AND METHODS}

\section{Composite Pheochromocytoma}

Five cases of the composite pheochromocytoma were excised and fixed in $10 \%$ of formalin and embedded in paraffin. Of these five, three cases were from the Tohoku University Hospital and the others were supplied by Dr. S. Sasou (the Iwate Medical School, Morioka, Japan) and Dr. Y. Taiki (the Sakashita hospital, Aichi, Japan). One of the five patients had cutaneous neurofibromatosis as a sign of NF1 (Case 1). The other patients had no signs of NF1. One of the neurofibromas of the skin of Case 1 and two ordinary pheochromocytomas without NF1 were submitted as controls for gene analysis of NF1 Exon 31. Clinicopathological data of the patients are summarized in Table 1. Some data from these patients have previously been reported $(13,14)$. All patients with composite pheochromocytoma are well without recurrence or metastasis after operation.

\section{Tumors Associated with NF1}

Various tumors of the five patients with NF1 were obtained from the Department of Pathology, Shonai hospital, Yamagata, Japan. Clinicopathological data are summarized in Table 2. Histologic diagnosis was carried out with ordinary hematoxylin-eosin stain and with immunohistochemical staining of chromogranin A.
DNA Isolation and PCR Amplification of NF1 Exon 31 in Composite Pheochromocytomas

DNA was extracted by a mixture of phenol and chloroform from the paraffin sections of the tumors fixed in $10 \%$ buffered formalin. PCR amplification and gene sequencing of NF1 exon 31 were carried out as described elsewhere (15), with a slight modification. Briefly, DNAs were amplified by PCR using primers flanking exon 31 of the NF1 gene, using the PCR primer pair 5'-CATTGACCATCACATGCTAATAGTG3' and the reverse primer 5'-TGAGCAAACTCAATACCTGCCCAAG-3'. The buffer and nucleotide components were as follows: each amplification reaction $(25 \mu \mathrm{L})$ included $0.5 \mu \mathrm{g}$ of genomic DNA, $200 \mu \mathrm{M}$ of each dNTP, $25 \mathrm{pM}$ of each primer, 0.625 units of Taq DNA polymerase, $10 \times$ PCR buffer, and distilled water. Each reaction mixture was predenatured for 4 minutes at $94^{\circ} \mathrm{C}$ and then subjected to 40 cycles of PCR (denaturation at $94^{\circ} \mathrm{C}$ for 1 minutes, primer annealing at $65^{\circ} \mathrm{C}$ for 2 minutes, and elongation at $72^{\circ} \mathrm{C}$ for 2 minutes). The final cycle was followed by an 8-min extension at $72^{\circ} \mathrm{C}$. The size of the amplified productivity was $248 \mathrm{bp}$. After amplification, a $5-\mu \mathrm{L}$ aliquot from each reaction was subjected to electrophoresis on nondenaturing $3 \%$ agarose gels and visualized with ethidium bromide.

Restriction enzyme digestion of PCR product was performed by incubating $10 \mu \mathrm{L}$ of PCR product, 4 $\mu \mathrm{L}$ of buffer, and $1 \mu \mathrm{L}$ of MaeIII enzyme at $55^{\circ} \mathrm{C}$ for 1.5 hours. Restriction enzyme digests were subjected to electrophoresis on nondenaturing $8 \%$ polyacrylamide gels and visualized with ethidium bromide (Fig. 1).

\section{Direct Sequencing}

For direct sequencing, Thermo Sequenase dye terminator cycle-sequencing premix kit, version 2 (Amersham) was used. The mixture $(20 \mu \mathrm{L})$ was composed of reagent mix A $(2 \mu \mathrm{L})$, reagent mix B (2 $\mu \mathrm{L})$, template $(0.2-2.0 \mu \mathrm{g}$; variable), primer $(1 \mu \mathrm{L}$; each, $5 \mathrm{pM}$ ), and variable distilled water.

Each reaction mixture was predenatured for 3 minutes at $96^{\circ} \mathrm{C}$ and then subjected to 25 cycles of PCR (denaturation at $96^{\circ} \mathrm{C}$ for 30 seconds, primer

TABLE 1. Summary of Patients with Composite Pheochromocytoma

\begin{tabular}{|c|c|c|c|c|c|c|}
\hline \multirow{2}{*}{ Case No. } & \multirow{2}{*}{ Age (y)/Sex } & \multirow{2}{*}{$\begin{array}{l}\text { Tumor Size } \\
(\mathrm{cm} / \mathrm{g})\end{array}$} & \multirow{2}{*}{ Histology } & \multicolumn{2}{|c|}{ Plasma CA (pg/mL) } & \multirow{2}{*}{ Comments } \\
\hline & & & & $\mathrm{NE}$ & $\mathrm{E}$ & \\
\hline 1 & $35 / \mathrm{M}$ & $10 \times 8 \times 6$ & Pheo + GNB & 4510 & 402 & von RHD \\
\hline 2 & $29 / \mathrm{F}$ & $9 \times 8.5 \times 8$ & Pheo + GNB & 4620 & 38 & - \\
\hline 3 & $42 / \mathrm{M}$ & $2 \times 2 \times 1.5$ & Pheo + GN & 510 & 130 & - \\
\hline 4 & $61 / \mathrm{F}$ & $5.5 \times 3 \times 3$ & Pheo + GN & 350 & 808 & - \\
\hline 5 & $45 / F$ & $5.6 \times 4.5 \times 2$ & Pheo + GN & 7900 & 143 & Bilateral and familial \\
\hline
\end{tabular}

CA, catecholamine; NE, norepinephrine; E, epinephrine; von RHD, von Recklinghausen's disease; Pheo, pheochromocytoma; GNB, ganglioneuroblastoma; GN, ganglioneuroma. 


\begin{tabular}{|c|c|c|c|}
\hline Case No. & Age $(y) / \operatorname{Sex}$ & Tumor Histology & $\begin{array}{l}\text { Comments } \\
\text { (Results Obtained) }\end{array}$ \\
\hline 1 & $68 / \mathrm{F}$ & $\begin{array}{l}\text { Pheochromocytoma, bilateral, gastric carcinoma and cutaneous } \\
\text { neurofibromatosis }\end{array}$ & Syringomyelia (autopsy) \\
\hline $2^{a}$ & $33 / \mathrm{F}$ & Neurofibromatosis infiltrating to cervical vein & Defect of skull (autopsy) \\
\hline 3 & $48 / \mathrm{F}$ & Neurofibromatosis infiltrating to cervical vein & Rupture of vein (autopsy) \\
\hline $4^{a}$ & $40 / \mathrm{M}$ & $\begin{array}{l}\text { Mucosal ganglioneuromatosis with two gangliocytic paraganglioma of } \\
\text { the rectum }\end{array}$ & (Operated) \\
\hline 5 & $12 / \mathrm{F}$ & Mucosal ganglioneuromatosis of the ileocecum, café au lait spot in skin & Ileus (operated) \\
\hline
\end{tabular}

${ }^{a}$ Has family history of neurofibromatosis.

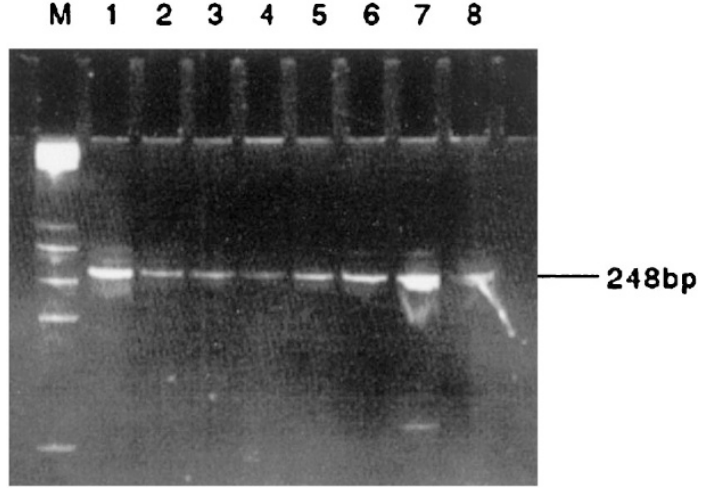

FIGURE 1. Restriction enzyme digestion of PCR product shows that all composite pheochromocytomas have NF1 gene product compatible with Exon 31. M, size marker; Lanes 1-5, composite pheochromocytoma of Cases 1-5, respectively; Lane 6, neurofibroma of the skin from a patient with composite pheochromocytoma (Case 1); Lanes 7 and 8, sporadic pheochromocytoma as control.

annealing at $50^{\circ} \mathrm{C}$ for 15 seconds, and elongation at $60^{\circ} \mathrm{C}$ for 4 minutes). After amplification, PCR products were purified with Sephadex G-50 column (Pharmacia) and kept frozen. The products were separated on sequence gel ( $6 \%$ polyacrylamide gel, $8 \mathrm{~m}$ urea, $1 \times \mathrm{TBE}$ ) and sequenced using ABI 373A sequencer (PE Biosystem, Urayasu, Japan). Sequencing was done in both forward and reverse directions with both strands of DNA. Because we did not have a positive control for a known mutation in Exon 31, we could not add a positive control.

\section{Immunohistochemistry}

Immunohistochemical study was performed using the Simple Stain Max kit (Nichirei, Tokyo, Japan), which is an enhancement method using peroxidase-conjugated amino acid polymer. The immunohistochemical procedure was as follows: after dewaxing the paraffin sections, the primary antibody was put on the sections at $4^{\circ} \mathrm{C}$ overnight and then washed three times with PBS. The sections were incubated into $10 \% \mathrm{H}_{2} \mathrm{O}_{2}$ solution to block the endogenous peroxidase. After washing with PBS, the sections were incubated in a second antibody labeled with amino acid polymer conjugated with peroxidase at $4^{\circ} \mathrm{C}$ for 60 minutes. Im- munoreactive products were visualized with a diaminobenzidine substrate.

The antibody for Nf1 gene-related peptide (neurofibromin) is an affinity-purified rabbit polyclonal antibody (1:150) raised against a peptide corresponding to residues 2798 to 2818 of the predicted NF1 gene product (Santa Cruz, CA). The specificity of this antibody was reported previously (16). To identify Schwann cells, serial sections were stained with S100 protein (S100p) antibody (1:1000, DAKO), which is an antibody known to detect Schwann cells $(17,18)$. For control study, normal rabbit serum was applied instead of the antibody of neurofibromin or S100p. For identifying pheochromocytoma, antibody for chromogranin A (1:1000, DAKO) was used.

\section{RESULTS}

For positive control, leukocytes in the blood vessels were always strongly positive as internal control for neurofibromin. Neurofibromin was detected in normal tissues such as epidermis, sweat gland, and hair follicle of the skin; ducts of the salivary gland; endothelial cells of vascular walls; striated muscles; and distal tubules of the kidney.

\section{Composite Pheochromocytoma:}

One tumor associated with NF1 showed weak staining for neurofibromin in ganglionic cells and pheochromocytoma cells and was negative for Schwann cells among nerve bundles. The other tumors without NF1 exhibited moderate to strong staining of neurofibromin in ganglionic and pheochromocytoma cells, but not in Schwann cells (Fig. 2). On the contrary, S100p was strongly detected in nerve bundles including Schwann cells and sustentacular cells; however, both types of tumor cells of ganglionic cells and pheochromocytoma cells were almost negative, except some cells that were sporadically positive for S100p (Fig. 3).

\section{Tumor-Associated NF1 Patients}

Pheochromocytoma in Case 1 showed focally thick nerve bundles in pheochromocytoma; however, its histology was not satisfactory for diagnosis 


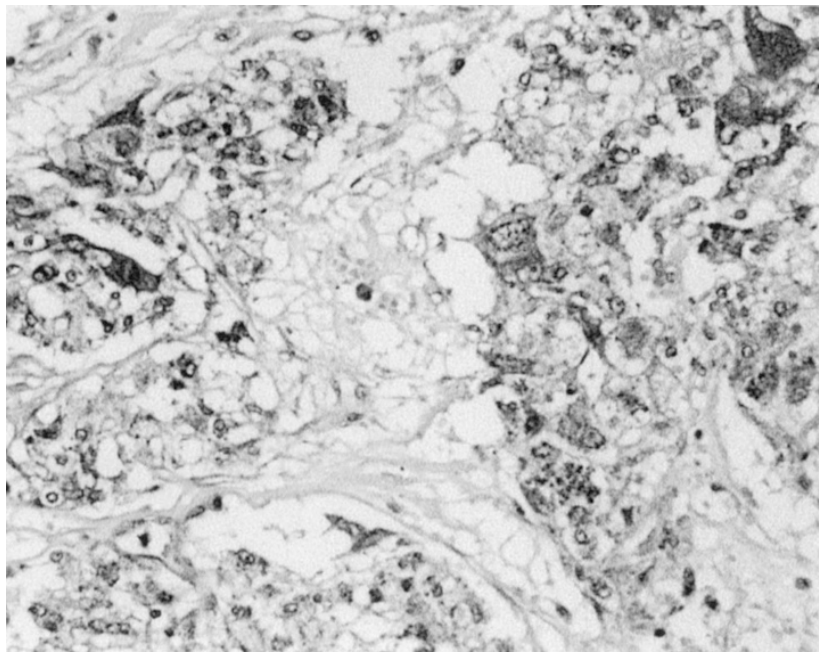

FIGURE 2. Composite pheochromocytoma. Marked neurofibromin immunoreactivity is observed in the majority of gangliocytic cells and pheochromocytoma cells, but not in nerve bundles and Schwann cells (slightly counterstained with hematoxylin).

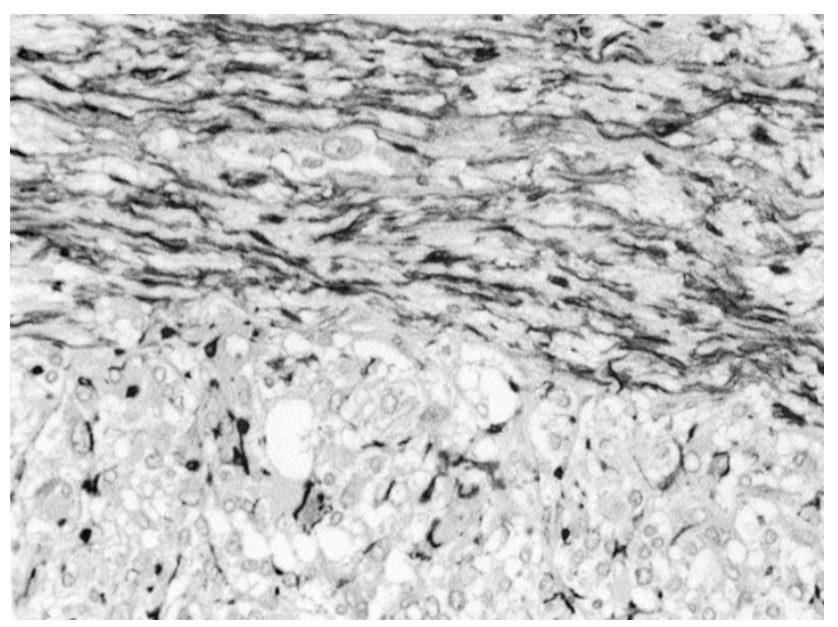

FIGURE 3. Same tumor as in Figure 2. Marked S100p immunoreactivity is observed in nerve bundles including Schwann cells; however, both gangliocytic cells and pheochromocytoma cells are completely negative for S100p (slightly counterstained with hematoxylin).

as composite pheochromocytoma. Thus, we just called this pheochromocytoma. Neurofibromin immunoreactivity was strongly expressed in pheochromocytoma cells but was negative or very weak in sustentacular cells or in nerve bundles (Fig. 4). S100p immunoreactivity was evident in sustentacular cells and nerve bundles but not in most pheochromocytoma cells, with some cells showing weakly positive staining (Fig. 5).

In mucosal GN, immunoreactivity for neurofibromin was strongly demonstrated in ganglionic cells, but not (or very weakly) in the Schwann cells of the nerve bundles (Fig. 6). On the contrary, S100p immunoreactivity was strongly positive in the Schwann cells of nerve bundles, but not in the ganglionic cells.

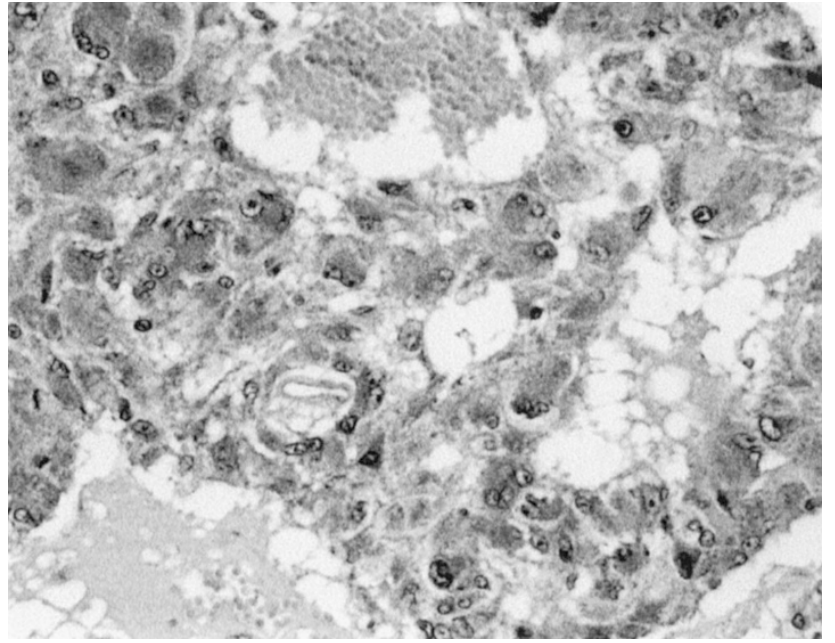

FIGURE 4. Pheochromocytoma of patient with NF1. Marked neurofibromin immunoreactivity is expressed in pheochromocytoma cells and very weakly in sustentacular cells or in nerve bundles (slightly counterstained with hematoxylin).

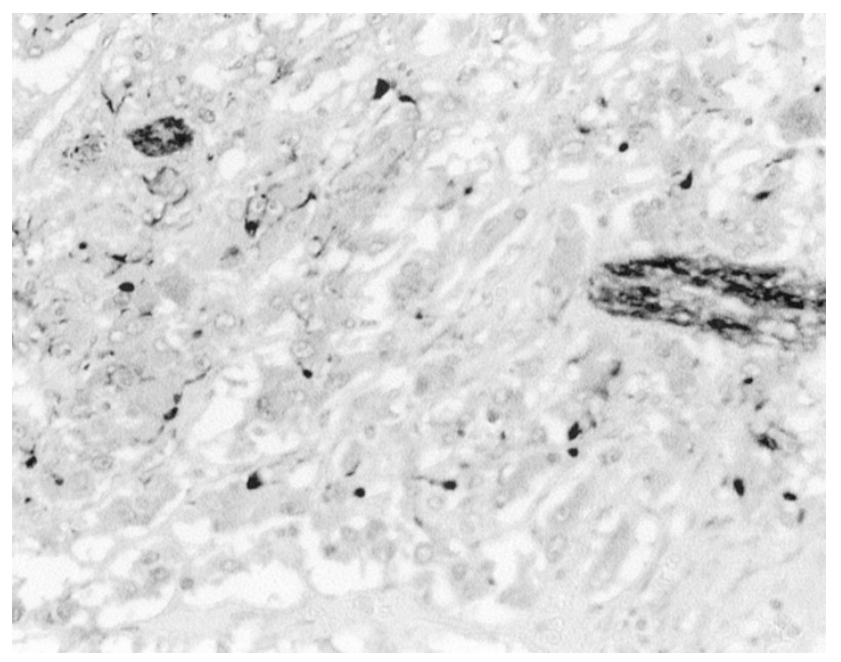

FIGURE 5. Same tumor as in Figure 4. S100p immunoreactivity is evident in sustentacular cells and nerve bundles, but not in pheochromocytoma cells (slightly counterstained with hematoxylin).

Gangliocytic paraganglioma in Case 5 showed weak immunoreactivity for neurofibromin in paraganglioma-like tumor cells and also in ganglionic tumor cells. Only the Schwann cells of the nerve bundles were positive for S100p, but not the other types of tumor cells.

Tumor cells of neurofibroma in cases with NF1, including a case of composite pheochromocytoma, showed almost negative or very weak immunoreactivity to neurofibromin (Fig. 7).

The results of the immunohistochemical study are summarized in Table 3.

The DNA sequence in the extracted, amplified, and digested DNA from the tumors of composite pheochromocytoma and GN/GNB was as follows:

\footnotetext{
GTATTGAATTGAAACACCTTTGTTTGGAATACATGACTCCATGGCTGT CA ${ }^{50}$
} 


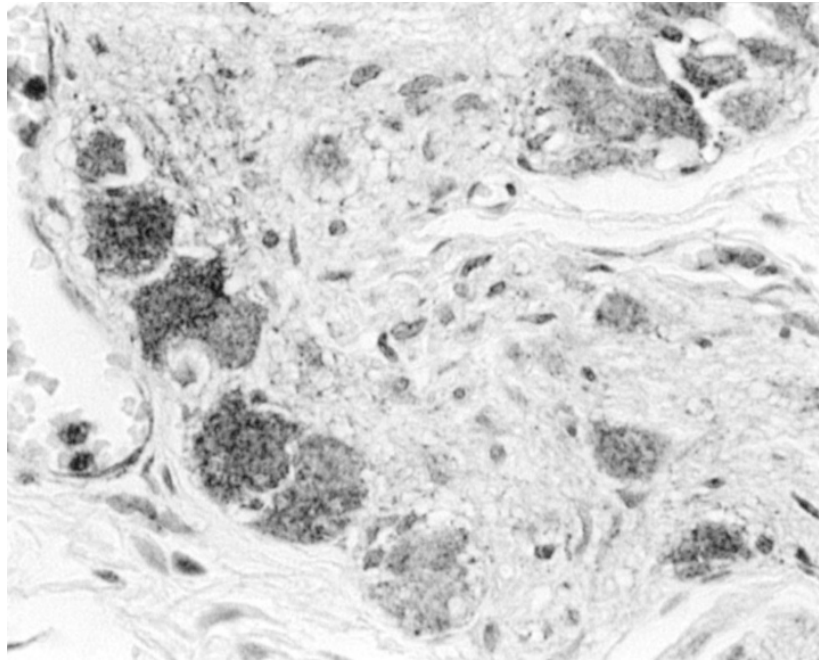

FIGURE 6. Mucosal ganglioneuroma of sigmoid colon from patients with NF1. Neurofibromin immunoreactivity is strongly observed in ganglionic cells and very weakly in the Schwann cells of the nerve bundles.

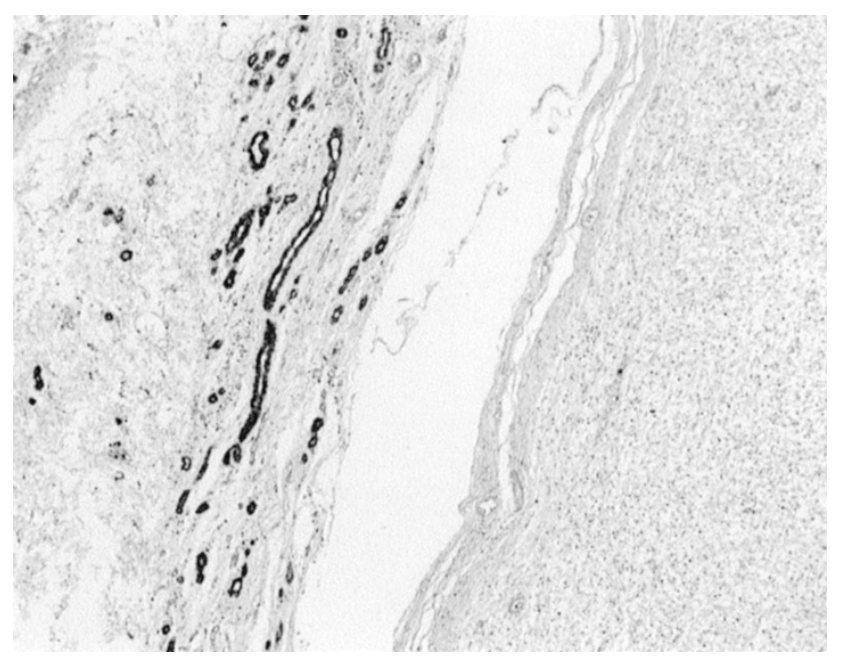

FIGURE 7. Neurofibroma of the parotis from the patient with NF1. The neurofibromin immunoreactivity is strong in ductal cells of the parotis (left side), but not or very weakly in neurofibroma (right side).

\section{AATCTAGTTCGTTTTTGCAAGCATAATGATGAT- GCCAAACGACAAAGAGT ${ }^{100}$ \\ TACTGCTATTCTTGACAAGCTGATAACAATGAC- CATCAATGAAAAACAGA ${ }^{150}$ \\ TGTACCCATCTATTCAAGCAAAAATATGGGGAA- GCCTTGGGCAG $^{194}$.}

This sequence was the same as that of the wild-type NF1 Exon 31, and there was no point mutation.

\section{DISCUSSION}

The risk of pheochromocytoma in patients with NF1 is in 0.1 to $5.7 \%(19,20)$; however, $23 \%$ of composite pheochromocytomas reported to be associated with NF1 (3). Bilateral classic pheochro-
TABLE 3. Immunohistochemical Results of Neurofibromin and S100p in Composite Pheochromocytoma and Tumors Associated with NF1

\begin{tabular}{lcc}
\multicolumn{1}{c}{ Tumor } & Neurofibromin & S100p \\
\hline Composite tumors & & - \\
Ganglionic cell & ++ & $-\sim+$ \\
Pheochromocyte & - & +++ \\
Sustentacular cell & - & +++ \\
Nerve bundle with Schwann cells & & $-\sim+$ \\
NF1-associated tumors & ++ & +++ \\
Pheochromocytoma & - & +++ \\
Sustentacular cell & - & +++ \\
Nerve bundle with Schwann cells & $\sim+$ & - \\
Neurofibroma & & +++ \\
Mucosal ganglioneuroma & - & - \\
Ganglionic cells & & ++ \\
Nerve bundle & +++ & - \\
Gangliocytic paraganglioma & - & + \\
$\quad$ Ganglionic cell & + & + \\
Nerve bundle & & + \\
Carcinoid-like cell &
\end{tabular}

mocytomas are rare in patients with NF1, and Chetty et al. (4) suggested that bilateral composite pheochromocytomas are an extension of this association. Patients with NF1-associated pheochromocytoma have been reported to show a loss of the wild-type allele of NF1 gene $(8,21)$. Loss of gene expression by reverse-transcribed polymerase chain reaction (RT-PCR) and the immunohistochemistry in sporadic pheochromocytomas without NF1 was also reported (22).

The NF1 gene is a tumor suppressor gene mapping to chromosome 17q11.2. Because of the large gene size (11 kb of coding sequence extending over $300 \mathrm{~kb}$ of genomic DNA, including 60 exons), extensive analysis of mutation has been difficult, and in only about $15 \%$ of patients are mutations identified (19). Several point mutations have been found in Exon 31 in NF1 patients (23). Brannan et al. (24) constructed a Nf1 mutant mouse with insertion of cassette in the opposite transcriptional orientation into Exon 31 of an NF1 genomic fragment. Homozygous mutant NF1 mice that died in utero showed cardiac anomalies and hyperplasia of the sympathetic ganglia. Jacks et al. (10) constructed a similar targeted mutation and reported various tumors that are evident in human NF1 patients including pheochromocytoma and the strongest evidence to date that Nf1 acts as a classical tumor suppressor gene. Neurofibromin is a highly conserved protein throughout evolution: mouse neurofibromin is over $98 \%$ identical with the human protein (9). Thus, neurofibromin is thought to be an important for tumorigenesis and tumor progression.

Neurofibromin-deficient Schwann cells have tumorigenic potential in vitro (25); however, NF1 heterozygous mutant mice had no neurofibromatosis $(10,24)$. All tumor cell lines from heterozygous mice expressed neurofibromin at much lower levels than PC12 cells (12). It has not been revealed whether tumor cells from such heterozygous mutant mice 
express immunohistochemical neurofibromin in tissue level. Our study revealed that neurofibromin immunoreactivity was very weakly or negatively observed in the Schwann cells in the tumors from patients with NF1 as well as in the composite tumors. Strong expression of neurofibromin in ganglionic cells and pheochromocytoma cells in composite tumors and various tumors from patients with NF1 is demonstrated by the present study.

It has been considered that pheochromocytes and sustentacular cells have an intimate relationship, like the relationship between neuron and glial cells in the brain that keeps homeostasis each other in existence. Neurofibromin negatively regulates neurotropin signaling through $\mathrm{p}(21)$ ras in embryonic sensory nerve proliferation (26). Some previous reports argued that loss of sustentacular cells induces proliferation of pheochromocytes and may develop into malignant pheochromocytoma (27). In contrast, we suggest that loss of neurofibromin may induce abnormal proliferation of Schwann cells and also increase neurotropins and results in marked proliferation of pheochromocytoma cells. Finally, it develops to be a composite pheochromocytoma, not necessarily in all but in some of the cases with NF1. Further study is necessary to confirm this hypothesis.

Acknowledgment: We thank Dr. K. Orikasa (Department of Urology, Tohoku Rasai Hospital, Sendai) for his helpful suggestions.

\section{REFERENCES}

1. Solcia E, Kloppel G, Sobin LH. Histological typing of endocrine tumours. WHO international histological classification of tumours. 2nd ed. Berlin: Springer-Verlag; 2000.

2. Nakagawara A, Ikeda K, Tsuneyoshi M, Daimaru Y, Enjoji M. Malignant pheochromocytoma with ganglioneuroblastomatous elements in a patient with von Recklinghausen's disease. Cancer 1985;55:2794-8.

3. Kimura N, Miura Y, Miura K, Takahashi N, Osamura YR, Nagatsu I, et al. Adrenal and retroperitoneal mixed neuroendocrine-neural tumors. Endocr Pathol 1991;2:139-47.

4. Chetty R, Duhig JF. Bilateral pheochromocytomaganglioneuroma of the adrenal in type I neurofibromatosis. Am J Surg Pathol 1993;17:837-41.

5. Satake H, Inoue K, Kamada M, Watanabe H, Furihata M, Shuin T. Malignant composite pheochromocytoma of the adrenal gland in a patient with von Recklinghausen's disease. J Urol 2001;165:1199-200.

6. Seizinger BR. NF1: a prevalent cause of tumorigenesis in human cancers? Nat Genet 1993;3:97-9.

7. Xu G, O'Connell P, Viskochil D, Cawthon R, Robertson M, Culver $\mathrm{M}$, et al. The neurofibromatosis type 1 gene encodes a protein related to GAP. Cell 1990;62:599-608.

8. Gutmann DH, Cole JL, Ponder BAJ, Collins FS. Loss of neurofibromin in adrenal gland tumors from patients with neurofibromatosis type 1. Genes Chromosom Cancer 1994;10:55-8.

9. Bernards A, Snijders AJ, Hannigan GE, Murthy AE, Gusella JF. Mouse neurofibromatosis type 1 cDNA sequence reveals high degree of conservation of both coding and non-coding mRNA segments. Hum Mol Genet 1993;2:645-50.
10. Jacks T, Shih TS, Schmitt EM, Bronson RT, Bernards A, Weinberg RA. Tumorigenic and developmental consequences of a targeted Nf1 mutation in the mouse. Nat Genet 1994;7:353-61.

11. Tischler AS, Shih TS, Williams BO, Jacks T. Characterization of pheochromocytomas in a mouse strain with a targeted disruptive mutation of the neurofibromatosis gene Nf1. Endocr Pathol 1995;6:323-36.

12. Poweres JF, Evinger MJ, Tsokas P, Bedri S, Alroy J, Shahsavari M, et al. Pheochromocytoma cell lines from heterozygous neurofibromatosis knockout mice. Cell Tissue Res 2000;302:309-20.

13. Watanabe T, Noshiro T, Kusakari T, Akama H, Shibukawa S, Miura W, et al. Two cases of pheochromocytoma diagnosed histopathologically as mixed neuroendocrine-neural tumor. Int Med 1995;34:683-7.

14. Fujiwara T, Kawamura M, Sasou S, Hiramori K. Results of surgery for a compound adrenal tumor consisting of pheochromocytoma and ganglioneuroblastoma in an adult: 5-year follow-up. Int Med 2000;39:58-62.

15. Ainsworth PJ, Rodenhiser DI, Costa MT. Identification and characterization of sporadic and inherited mutations in exon 31 of the neurofibromatosis (NF1) gene. Hum Genet 1993;91:151-6.

16. Gutmann DH, Wood DL, Collins FS. Identification of the neurofibromatosis type 1 gene product. Proc Natl Acad Sci U S A 1991;88:9658-62.

17. Tischler AS, Dayal Y, Balogh K, Cohen RB, Connolly JL, Tallberg K. The distribution of immunoreactive chromogranins, S-100 protein and vasoactive intestinal peptide in compound tumors of the adrenal medulla. Hum Pathol 1987;18:909-17.

18. Kimura N, Nakamura M, Kimura I, Nagura H. Tissue localization of nerve growth factor receptors: trkA and lowaffinity nerve growth factor receptor in neuroblastoma, pheochromocytoma, and retinoblastoma. Endocr Pathol 1986;7:281-9.

19. Koch CA, Vortmeyer AO, Huang SC, Alesci S, Xhuang Z, Pacak K. Genetic aspects of pheochromocytoma. Endocr Regal 2001;35:43-52.

20. Walther MM, Herring J, Enquist E, Keiser HR, Linehan WM. Von Recklinghausen's disease and pheochromocytomas. J Urol 1999;16:21582-6.

21. Xu W, Mulligan LM, Ponder MA, Smith BA, Mathew CGP, Ponder BAJ. Loss of NF1 alleles in pheochromocytomas from patients with type 1 neurofibromatosis. Genes Chromosom Cancer 1992;4:337-42.

22. Gutmann DH, Geist RT, Rose K, Wallin G, Moley JF. Loss of neurofibromatosis type 1 (NF1) gene expression in pheochromocytomas from patients without NF1. Genes Chromosom Cancer 1995;13:104-9.

23. Cawthon RM, Weiss R, Xu G, Viskochil D, Culver M, Stevens J, et al. A major segment of the neurofibromatosis type 1 gene: cDNA sequence, genomic structure, and point mutations. Cell 1990;82:193-201.

24. Brannan CI, Perkins AS, Vogel KS, Ratner N, Nordlund ML, Reid SW, et al. Targeted disruption of the neurofibromatosis type-1 leads to developmental abnormalities in heart and various neural crest-derived tissues. Genes Dev 1994;8:1019-29.

25. Muir D, Neubauer D, Lim IT, Yachnis AT, Wallace MR. Tumorigenic properties of neurofibromin-deficient neurofibroma Schwann cells. Am J Pathol 2001;158:501-13.

26. Vogel KS, El-Afandi M, Parada LF. Neurofibromin negative regulates neurotrophin signaling through p21ras in embryonic sensory neurons. Mol Cell Neurosci 2000;15:398-407.

27. Unger P, Hpffman K, Pertsemlidis D, Yhung S, Wolfe D, Kaneko M. S100 protein-positive sustentacular cells in malignant and locally aggressive adrenal pheochromocytomas. Arch Pathol Lab Med 1991;115:484-7. 